Bartın Üniversitesi

Eğitim Fakültesi Dergisi

Cilt 6, Sayı 2, s. 596-613, Haziran 2017

BARTIN - TÜRKIYE

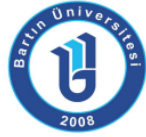

ISSN: 1308-7177
BartinUniversity

Journal of Faculty of Education

Volume 6, Issue2, p. 596-613, June 2017

BARTIN - TURKEY

\title{
2005 Fen ve Teknoloji ve 2013 Fen Bilimleri Öğretim Programı Madde ve Değişim Öğrenme Alanı Kazanımlarının Karşılaştırmalı Analizi
}

\author{
Güngör KESKINKILIÇ YUMUŞAK, Yrd. Doç. Dr., Necmettin Erbakan Üniversitesi Ahmet Keleşoğlu Eğitim Fakültesi, \\ gyumusak@konya.edu.tr
}

Öz: Bu araştırmada 2005 yılında uygulamaya konulan Fen ve Teknoloji öğretim programı ile 2013 yılında uygulamaya konulan Fen Bilimleri öğretim programının kazanım boyutu karşılaştırmalı olarak analiz edilmiştir. Araştırmada nitel araştırma yöntemlerinden biri olan doküman analizi yapılmıştır. Doküman olarak öğretim programları ve 4, 5, 6, 7 ve 8. Sınıf düzeylerine ait ders kitaplarının madde ve değişim öğrenme alanı kullanılmıştır. Araştırmada veriler içerik analizi kullanılarak çözümlenmiştir. Araştırmada öncelikle programların genel amaçları karşılaştırılmış sonra kazanımlar karşılaştırılarak sonuçlar yorumlanmıştır. Programların kazanımlarının yapısı karşılıklı olarak incelendiğinde 2013 fen bilimleri programı madde ve değişim öğrenme alanı kazanımlarının oldukça genel ve kapsamlı olarak ifade edildiği belirlenmiştir. Ayrıca 2013 Fen programları Madde ve Değişim ünitesine ilişkin kazanımların 2005 programlarına kıyasla yedinci sınıf hariç diğer tüm sınıf düzeylerinde yaklaşık olarak 1/3 oranında daha az olduğu belirlenmiştir. 2013 programlarında FTTÇ, bilimsel süreç becerileri, duyuş ve ara disiplin alanlarına ilişskin ayrı bir başlık altında kazanım listelerine yer verilmediği, bu alanlara ilişkin kazanımların bilgi öğrenme alanına ilişkin kazanımlara yedirildiği belirlenmiştir.

Anahtar Kelimeler: Fen eğitimi, fen programları, öğretim programları, program analizi, eğitsel kazanımlar

\section{Comparative Analysis of 2005 Science and Technology and 2013 Science Curriculum Matter and Change Learning Area \\ Achievements}

\begin{abstract}
In this research, the science and technology curriculum started to be implemented in 2005 and the science curriculum started to be implemented in 2013 have been analyzed comparatively in terms of learning outcomes. Document analysis method which is one of the qualitative research methods was used in the research. Curriculum documents and 4, 5, 6, 7th and 8th grade textbooks were used as a document. The data in were analyzed using content analysis. In the research, the then the learning outcomes of the curricula were compared and interpreted. When the structure of the learning outcomes of the curriculum documents is mutually examined, it has been determined that the learning outcomes of the 2013 science curriculum are expressed in a very general and comprehensive manner. In addition, it was determined that the learning outcomes for the 2013 Science curricula Matter and Change unit were less than one-third of all class levels except for the 7th grade compared to 2005 programs.It is determined that the 2013 programs do not includethelist of "STSE (Science, Technology, Societyand Environment), Scientific Process Skills and Affective Skills learning outcomes" and the learning outcomes related to these areas are given to the gains related to the field of knowledge dimensions of the curricula.
\end{abstract}

Key Words: Science education, science curricula, curriculum issues, analyses of curricula, learning outcomes 


\section{GíRiş}

Eğitimde programlar, kazanımlardanöğretim uygulamalarına kadar tüm çalışmalara kılavuzluk etmekte ve böylece ülkenin eğitim politikasının uygulamaya dönüştürülmesini sağlayan bir köprü görevi görmektedir (Varış, 1997). Eğitim programı, "kişide gözlemlenmesi kararlaştırılan hedefleri, bunları gerçekleştirebilecek düzenli eğitim ve sınama durumlarını içeren dirik bir bütün"( Sönmez, 1993: 7) olarak tanımlanabilir. Kişide gözlemlenmesi kararlaştırılan özellikler istendik davranışlardır ve eğitimin "istendik" davranışları oluşturma (Ertürk, 1972) hedefinin gerçekleştirilmesi, eğitim programları vasıtası ile sağlanabilir. Bu nedenle bir programı tasarlama, uygulama ve değerlendirme bir bütün olarak görülmeli, çalışmalar her aşamada değerlendirilmeli ve düzenlenmeli (Çepni ve Çil, 2016) ve ayrıca, bireyi, toplumu ve bilgi yapısını etkileyen gelişmeler ışığında değiştirilmelidir (Görgen, 2012).

Birçok ülkede olduğu gibi Türkiye'de de son yıllarda öğretim programlarında dikkat çekici yapılandırmalar gerçekleştirilmiştir. 2004 yılında Millî Eğitim Bakanlığı ve Talim Terbiye Kurulu Başkanlığı işbirliği ile öğretim programları eski programların yetersizlikleri, uluslararası öğrenci değerlendirmelerinde alınan başarısız sonuçlar, eğitimde kaliteyi artırma ihtiyacı ve dersler arasında bütünlüğün sağlanması ihtiyacı gibi gerekçelerle yapılandırmacı yaklaşım dikkate alarak yeniden geliştirilmiştir (Kıroğlu, 2006). Programlar bir süre uygulandıktan sonra, 2012-2013 öğretim yılında 12 yıllık kademeli zorunlu eğitime geçilmiştir. Bu sistemde ilk 4 yıl ilkokul, ikinci 4 yıl ortaokul ve üçüncü 4 yıl ise lise olarak tanımlanmıştır. Dolayısıyla sistem değişikliğinin hemen ardından programların yenileneceği dönemin Milli Eğitim Bakanı tarafından bildirilmiş (MEB, 2012) yeni sistemin ihtiyacını karşılayabilmek için yeniden bir program düzenlemesine gidilmiştir (Karatay vd., 2013; Toraman ve Alcı, 2013; Eskicumalı vd., 2014). Bu düzenlemeye fen derslerinin programları da dâhil edilmiştir. Yeni düzenleme ile beraber fen ve teknoloji dersinin adı fen bilimleri olarak değiştirilmiş, 3. Sınıflardan itibaren okutulmaya başlanması kararlaştırılmış ve Talim ve Terbiye Kurulunun 01.02.2013/7 tarih ve sayılı kararıyla 2014-2015 öğretim yılından itibaren uygulamaya konulmuştur.

2004 yılında geliştirilen öğretim programları derslerin işleniş yöntemlerinde, öğretmenöğrenci rollerinde ve ölçme - değerlendirme yaklaşımlarında önemli yenilikleri hedeflemiştir (Aydın ve Çakıroğlu, 2010). Zira 2005 yılında uygulamaya konulan fen ve teknoloji dersi öğretim programlarının yapılandırmacı bir anlayış esas alınarak ve "reform kelimesinin içini dolduracak bir vizyonla" hazırlandığı (MEB, 2005) belirtilmiştir. Diğer taraftan 2013 fen bilimleri programının reform niteliğinde büyük bir değişime uğradığı söylenemez. 2013 programları, 2005 programlarının yeni sisteme göre güncellenmiş hali olarak tanımlanmaktadır. Çepni ve Çil (2016) 2013 yılında uygulamaya konulan fen bilimleri dersi öğretim programının 12 yıllık zorunlu eğitime geçilmesi, eski programlardaki; kazanım yükünün fazla olması, duyuşsal öğrenme alanının ihmal edilmesi, becerilerin yeterince vurgulanmaması, sürdürülebilirlik ve sosyal bilimsel konulara ağırlık vermemesi gibi hususlardan dolayı güncellenmiş olabileceğini belirtmişlerdir. Zira 4+4+4 sisteminin ardından programlardaki değişikliklerin bir tür "uyarlama" olacağı ve ders kitaplarında "bazı değişiklikler" in yapılacağı dönemin Milli eğitim bakanlığı tarafından da ifade edilmiştir (MEB, 2012). Milli Eğitim Bakanlığı YEĞiTEK (Yenilikçi Eğitim Teknolojileri Kurumu) Birimi tarafından hazırlanan program tanıtım videosunda (Fen Bilimleri Dersi (3-8. Sınıflar) Öğretim Programı Tanıtımı, 2013) fen bilimleri dersi öğretim programının "güncellenme" sinin gerekçesinin ise, "sade, anlaşılır ve uygulanabilir bir program" ihtiyacından kaynaklandığı belirtilmiştir.

Eğitim sistemlerinin en önemli çarklarından biri olan programları geliştirmeye ilişkin faaliyetler sürerken bu faaliyetler kapsamında ne tür değişiklik ve uyarlamaların yapıldığının analiz edilmesinin önemi kaçınılmazdır. Alan yazında, geliştirilen programın önceki programlarla karşılaştırmalı analizine ilişkin çalışmalar mevcuttur. Yücel ve Özkan (2013) 
yaptıkları araştırmada 2005 ve 2013 programlarını çevre konuları açısından analiz etmişler, konu dağılımı ve ayrılan süre bakımından yeni programda önemli değişikliklerin olduğunu belirlemişlerdir. Ayrıca birçok konuda kazanımlarının azaltıldığını, bazı konulardaki kazanımların artırıldığını ve bazı kazanımlarının ise programdan tamamen çıkarıldığını, bununla birlikte yeni programda çevre konularına ayrılan sürenin azaltıldığını belirlemişlerdir. Karatay, Timur ve Timur (2013) 2013 öğretim programı ile birlikte kazanım sayılarının büyük oranda azaltıldığını, konu alanları içerisinde bulunan ünitelerden bir kısmının isminin değiştirildiğini, ders saati sürelerinde değişikliklere gidildiğini, araştırma-sorgulamaya dayalı öğrenme stratejisinin vurgulandığını belirlemişlerdir. Eğitim ve Bilişim Ağında(EBA) yer alan program tanıtım videosunda (Fen Bilimleri Dersi (3-8. Sınıflar) Öğretim Programı Tanıtımı, 2013) da benzer şekilde programın sadeleştirildiği, kazanımların önceki programdaki birkaç kazanımı içerecek şekilde ifade edildiği, bununla birlikte kazanımlarda belli oranda kısıtlamaya gidildiği belirtilmiştir. Program tanıtımında programın ana gerekçelerinden biri olarak "sade ve anlaşıır bir program ihtiyacının öğretmenler tarafından dile getirilmiş olması" gösterilmektedir. Bu tanımlamaya paralel bir şekilde Karaman ve Karaman (2016)'ın yaptığı araştırmaya göre öğretmenler de programı sade ve anlaşılır olarak tanımlamışlar, kazanım sayılarının azaltılmasını olumlu karşılaşmışlardır. Aynı çalışmada öğretme ve öğrenme süreci ile ilgili yeniliklerin olumlu karşılandığı ancak olanakların öğrenci merkezli birçok uygulamayı gerçekleştirmede yetersiz kaldığı ve programlarla ilgili öğretmenlerin yeterince bilgilendirilmediği belirlenmiştir.

Bilindiği üzere kazanımlar programın diğer ögelerine de yön vermektedir ve bu nedenle programın en önemli ögesi olarak görülebilir. Kazanımlarda meydana gelen bir değişiklikten söz edilmesi bu konuda programlarda ne şekilde düzenlemelerin yapıldığının ayrıntılı analizini gerekli kılmaktadır. Ancak bu konuda alan yazında var olan çalışmaların yetersiz olduğu görülmektedir. Bu nedenle kazanım boyutunun önceki programla karşılaştırmalı olarak analizine intiyaç duyulmuştur. Programlarda yapılan değişiklik ve düzenlemelerin analiz edilmesini içeren çalışmalar ilerleyen yıllarda yapılacak olan düzenlemeler için yön gösterici olabilir. Bu çalışmanın bu ihtiyaca cevap verebilecek nitelikte olduğu düşünülmektedir. Ayrıca bu analizin 2013 programının 2005 programından kazanım boyutu açısından farklılaştığı noktaları açık ve ayrıntılarıyla görebilmeyi sağlayacağı düşünülmekte ve bu sayede öğretmenlere, program geliştirme uzmanlarına ve araştırmacılara kazanımlarla ilgili olarak yapılan değişikliklere ilişkin derinlemesine ve somut bilgi sağlaması umulmaktadır. Bu araştırmanın amacı 2013 yılında uygulamaya konulan Fen bilimleri öğretim programı ile 2005 yılında uygulamaya konulan Fen ve Teknoloji öğretim programının kazanımlarını karşılaştırmalı olarak analiz etmektir.

Bu amaç çerçevesinde aşağıdaki sorulara yanıt aranmıştır.

1. 2005 ve 2013 programlarının kazanımları arasındayapısal olarak ne tür farklılıklar vardır?

2. 2005 ve 2013 programının kazanım sayılarıve sınıflara göre dağııımları farklılaşmakta midır?

\section{YÖNTEM}

\subsection{Araştırma Deseni}

Araştırma, nitel araştırma desenlerinden doküman analizi ile gerçekleştirilmiştir. Doküman analizi; var olan yazılı dokümanların incelenmesi ve bu yolla araştırılmak istenen olgular hakkındaki bilgilerin ortaya çıkarılmasını kapsar (Yıldııı ve Şimşek, 2006). Bu araştırmada doküman olarak 2013 yılında uygulamaya konulan fen bilimleri dersi öğretim 
programı, 2005 yılında uygulamaya konulan fen ve teknoloji dersi öğretim programıve bu programların uygulanması için yazılan ve MEB tarafından onaylanan ders kitapları incelenmiştir. Analizler her iki programa ait dokümanlar karşılaştırılarak yapılmıştır. Araştırma kazanımların karşılıklı olarak incelenmesini içermektedir.

\subsection{Evren ve Örneklem}

Araştırmada tüm sınıf düzeyleri için bir öğrenme alanı (Madde ve Değişim) seçilmiş ve kazanımları incelenmiştir. Araştırmada kazanımlarda ne türde bir değişikliğin olduğunu belirlemek maksadıyla her iki programda yer alan "Madde ve Değişim" öğrenme alanlarındaki kazanımlar tüm sınıf düzeyleri dikkate alınarak karşılaştırılmıştır. Madde ve değişim öğrenme alanlarındaki kazanımların dikkate alınmasının nedeni, bu öğrenme alanının en geniş konu yapısına ve en fazla kazanıma sahip olmasıdır. Bu sayede programın bütününü daha iyi temsil edeceği düşünülmüştür. Ancak bununla birlikte bazı değişimlerin sadece incelenen öğrenme alanı için mi yoksa tüm program için mi gerçekleştirildiğini anlamak maksadıyla incelenen olgu kapsamında tüm program gözden geçirilmiştir. Programlar karşılaştırılırken 2005 ve 2013 programı kazanımlarının genellik bakımından farklı şekilde ifade edildiği belirlenmiş ve bu nedenle sadece kazanımların ele alınması yetersiz görülmüştür. Bunun için, programı uygulamanın en önemli yardımcı kaynaklarından biri olarak ders kitapları da karşılıklı olarak incelenmiştir. Tablo 1 de yer alan konunun kazanımlarının analizinde olduğu gibi tüm sınıf düzeylerinde yer alan kazanımlar ders kitapları ile birlikte incelenerek analiz edilmiştir. Analiz sonucunda 2005 programında olup ta 2013 programında yer almayan, diğer taraftan 2013 programında olup ta 2005 programında yer almayan kazanımlar tablolaştırılmıs ve kazanımlarda ne kadar kısıtlamaya gidildiği böylelikle gösterilmiştir.

\subsection{Verilerin Analizi}

Araştırmada veriler içerik analizi ile analiz edilmiştir. Bulgularda da betimlendiği gibi kazanımlarınifade biçimlerinde her iki programda farklııklar vardır. 2013 yılında geliştirilen programların kazanım ifadeleri daha kapsamlıdır, ancak kapsamın sınırını ilk bakışta anlamak mümkün görünmemektedir. O nedenle kazanımlar ders kitaplarında işlenen konular da dikkate alınarak, 2005 program kazanımları çerçevesinde incelenerek, hangi kazanımlara 2013 programında yer verildiği, hangi kazanımlara yer verilmediği, farklı olarak hangi kazanımların 2013 programında yer aldığı, kazanımlarda ne düzeyde bir kısıtlamaya gidildiği ortaya konmaya çalışılımıştır.

\subsection{Araştırmanın Kapsam ve Sınırlılıkları}

Bu araştırma fen programlarının kazanım boyutunu önceki programla karşılaştırarak analiz etmek üzere tasarlanmıştır. 2013 yılında önemli bir değişiklik olarak Fen Bilimleri dersinin 3. Sınıflardan itibaren okutulmaya başlanması kararlaştırılmıştır. Bununla birlikte bu araştırmada sınıf düzeyleri esas alınarak kazanımların karşılıkı analizi gerçekleştirildiğinden 3. Sınıf kazanımları analize dahil edilmemiştir. Araştırma 2005 yılında uygulamaya konulmuş olan fen ve teknoloji dersi öğretim programı ile 2013 yılında uygulamaya konulan fen bilimleri dersi öğretim programının madde ve değişim öğrenme alanı kazanımlarının karşııklı analizi ile sınırlıdır. Konuların ve kazanımların kapsamı ve sayısı düşünülerek örneklem olarak "Madde ve Değişim" öğrenme alanına ilişkin kazanımlar dikkate alınmış ve bu kazanımlar 4-5-6-7 ve 8. sınıflar dikkate alınarak dikey boyutta irdelenmiştir.

\section{BULGULAR}

Bulgular kısmında kazanımların yapısal özellikleri kapsamında kazanımların ifade ediliş biçimi, sayıları ve kapsamındane tür değişikliklerin olduğuna ilişkin karşılaştırma verilerine yer verilmiştir. 


\section{Bulgular}

\subsubsection{5 ve 2013 Programlarının Kazanımlarının ifade Ediliş Şekli ve Kapsamına ilişkin}

2013 Fen bilimleri programında dikkati çeken hususlardan birisi kazanımların oldukça az sayıda olmasıdır. Ancak Programların tanıtımlarında da bahsedildiği gibi kazanımların kapsamı da farklılaşmıştır. Bu bağlamda değerlendirildiğinde kazanımların kapsamı dikkate alınarak kazanımlarda ne düzeyde bir kısıtlamaya gidildiğinin belirlenmesi gerekmektedir. Bu amaçla iki programda yer alan aynı konulara ait kazanımlar ayrıntılı olarak karşılaştırılmıştır. Konuların belirlenmesinde her iki programda da benzer olarak işlenen konular dikkate alınmıştır.

Illk olarak "2005 ve 2013 programlarının kazanımları arasında yapısal ne tür farklılıklar vardır?"sorusu yanıtlanmaya çalışılmıştır. Bu soru kapsamında programlarda yer alan kazanımların ifade ediliş biçimleri ve kapsamları 4. Sınıf Madde ve Değişim Öğrenme alanlarına ilişkin her iki programda yer alan bir konunun kazanımları aşağıdaki tablolarda örneklendirilerek irdelenmiştir.

Tablo 1

2005 Fen ve Teknoloji ve 2013 Fen Bilimleri Programlarının Kazanımlarının ifade Ediliş Şekli ve Kapsamı

\section{KAZANIMLAR}

\section{Madde, cisim, malzeme ve eşya kavramlarıyla ilgili olarak öğrenciler;}

1. Maddeleri beş duyu organı ile fark edilen özellikleri ile niteler (BSB-1, 2, 3, 4).

2. Maddeleri beş duyu organı ile fark edilen özelliklerine göre sınıflandııır (BSB-1, 2, 3, 4, 5, 6).

3. Varlıkların sınıflandırılmasında belirsizlik olabileceğinin farkına varır (FTTÇ-2).

:- $\quad$ 4. Anlaşmazlık hâlinde bilimin önemini kavrar; Atatürk'ün akıl ve bilim ile sorunlara nasıl yaklaştığını açıklar (BSB-22, 23, 24; FTTÇ-2).

5. Madde, cisim, malzeme, eşya, alet vb. kavramları cümle içinde doğru olarak kullanır (BSB-3, 4,

$5,6)$.

6. Mıknatıslar tarafından çekilen ve çekilmeyen maddeleri ayırt eder (BSB-5, 6, 15).

7. Maddeleri suda yüzme - suda batma, ıslanma - kuru kalma, su çekme - çekmeme özelliklerine göre sınıflandırır (BSB-1, 2, 3, 4, 5, 6).

8. Maddelerin özellikleri ile gündelik hayatta kullanım alanları arasında ilişki kurar (FTTÇ-4).

9. Atatürk'ün akılcılığa ve bilime verdiği önemi fark eder.

Maddeyi Niteleyen Özellikler

1. Beş duyu organını kullanarak maddeyi niteleyen temel özellikleri açıklar.

Madde ve Cisim

2. Madde ve cismi tanımlayarak aralarındaki farkları açıklar.

Tablo 2

2005 Fen ve Teknoloji ve 2013 Fen Bilimleri Programlarının Kazanımlarının Işslenen Konular Dahilinde Temsil Ediliş Şekli ve Kapsamı

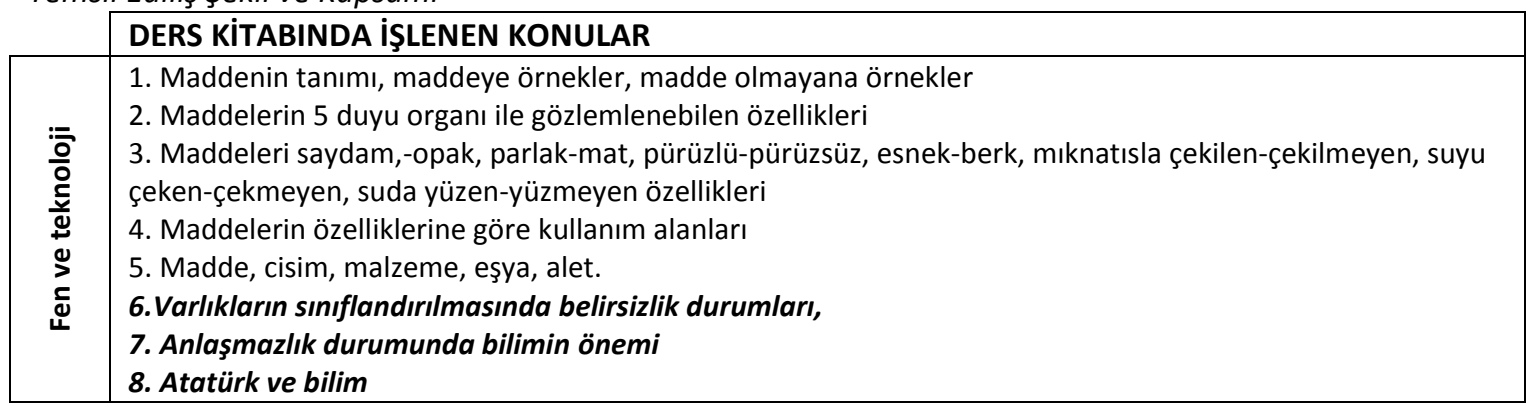




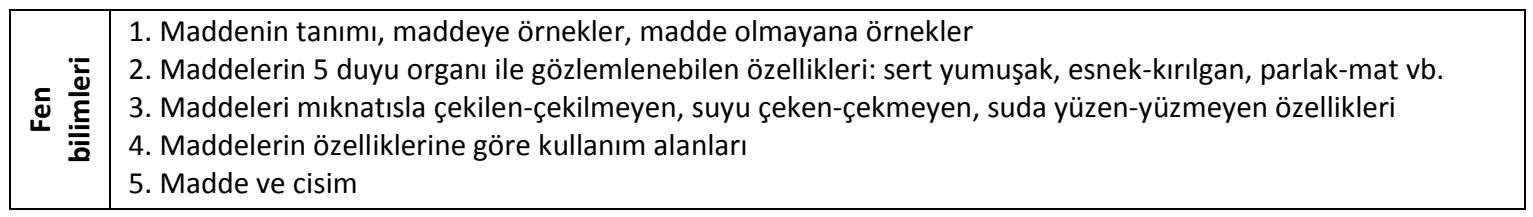

Tablo 3

2005 Fen ve Teknoloji ve 2013 Fen Bilimleri Programlarının Kazanımlarına ilişkin Olarak Verilen Açıklamalar ve Kapsamı

\begin{tabular}{|c|c|}
\hline & KAZANIMA iLIŞKIN AÇIKLAMALAR \\
\hline 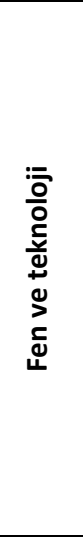 & $\begin{array}{l}\text { Kazanım 3'e ilişkin: Bir maddenin cisim, eşya ya da malzeme olduğu gibi tereddüte düşülen hâllerde, bu } \\
\text { kavramlar arasında çok keskin bir sınır olmadığı, bunların kullanıldığı yere göre farklı isimler alabildiği, bazı } \\
\text { durumlarda birinin yerine ötekinin de kullanılı̆ğı vurgulanır. } \\
\text { Kazanım 2'e ilişsin: Türkçe dersi Dinleme öğrenme alanı; Dinlediğini Anlama } \\
\text { Kazanım3, } 4 \text { ve9 a ilişkin: Maddeleri sınıflamada ortaya çıkabilecek belirsizlikleri gidermek için ölçmenin, } \\
\text { bilimsel yaklaşımın ve akılcılığın önemi vurgulanıp buradan, Atatürkçülük ile ilgili } 1.9 \text { kazanımına geçilebilir. } \\
\text { Kazanım 4'e ilişkin: “Ne Nedir, Nasıl Bileceğiz?” etkinliğinin arkasından Atatürk'ün kişiliğinin ilgili yönünü } \\
\text { açıklayan bir okuma parçası verilir. } \\
\text { Kazanım } 4 \text { ve 9’a ilişkin: Atatürkçülük ile ilgili konular } \\
\text { Kazanım 5'e ilişkin: Malzeme, eşya ve alet kavramları ilgili maddenin işlevi temelinde verilir; araç ve gereç } \\
\text { kavramlarının kullanıldığı ara durumlar örneklendirilir. } \\
\text { Kazanım } 7 \text { ye ilişkin: Yüzme ve batmanın sebebi ve yoğunluk ile ilişkisi 5. sınıf Fen ve Teknoloji Ünite 2'de ele } \\
\text { alınacaktır. } \\
\text { Kazanım 8'e illişkin: Şemsiye yapımı” öğrencilere proje konusu olarak verilebilir. }\end{array}$ \\
\hline 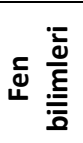 & $\begin{array}{l}\text { Kazanım 1'e ilişkin: } \\
\text { Maddeyi niteleyen; suda yüzme ve batma, suyu çekme ve çekmeme ve mıknatısla çekilme özelliğine } \\
\text { değinilir. }\end{array}$ \\
\hline
\end{tabular}

Madde ve Değişim öğrenme alanına ilişkin olarak yukarıdaki tablolarda yer alan kazanımlar, kazanımların ders kitaplarındaki temsil ediliş̧ biçimi ve kazanımlara ilişkin açıklamalar karşılıklı olarak incelendiğinde kazanımların 2013 programında daha genel ve kapsayıcı olarak ifade edildiği açıkça görülmektedir. Kazanım ifadelerinin genelliği2013 programlarındakapsam konusundabir belirsizlik hissettirmektedir. 2005 program kazanımları daha ayrıntılı ifade edilmiş olmasının yanında açıklamalar da ayrıntılı olarak yapıımıştır. Ancak 2013 programları kazanımları daha genel olarak ifade edilmesinin yanında açıklamalar da azaltılmışır ve işlenecek konuların sınırlandırılmasına ilişkin verilen açıklamalar yeterli görünmemektedir. Bu bakımdan ders kitaplarında konunun hangi kapsamda ele alındığına bakma gereği hissedilmiş ve tabloya buna ilişkin bilgiler eklenmiştir. Buna göre konular incelendiğinde hemen hemen aynı konuların ders kitaplarında da işlendiği görülmektedir. Ancak tablodan da görüleceği üzere, 2013programlarında"Varlıkların sınıflandırılmasında belirsizlik durumları", "Anlaşmazlık durumunda bilimin önemi" ve "Atatürk'ün akılcılığa ve bilime verdiği önem"e ilişkin kazanımların yer almadığı görülmektedir. Genel olarak programların tümü incelendiğinde buradaki örneğe benzer şekilde bir kazanımın en az iki ve ya daha fazla kazanımı içinde barındırdığı görülmektedir.

Kazanımlar karşılaştırıldığında dikkat çeken diğer bir husus FTTÇ ve BSB kazanımlarına 2013 programlarında atıfta bulunulmaması ve ayrıca bu alanlara ilişkin kazanımların ifade edilip listelenmemesidir. EBA'da yer alan program tanıtımında(Fen Bilimleri Dersi (3-8. Sınıflar) Öğretim Programı Tanıtımı, 2013) Fen'e özgü becerilerin (BSB, FTTÇ, Tutum ve Değerler) yeni programda bilgi kazanımlarına "yedirildiği" ifade edilmiştir. Ayrıca Fen bilimleri programında program şu şekilde tanımlanmıştır;

“Fen Bilimleri Dersi Öğretim Programında, tüm öğrencilerin fen okuryazarı olması vizyonunun gerçekleştirilebilmesi için Canlılar ve Hayat, Madde ve Değişim, Fiziksel Olaylar 
ve Dünya ve Evren konu alanları ile Beceri, Duyuş, Fen-Teknoloji-Toplum-Çevre (FTTÇ) öğrenme alanları belirlenmiştir. Öğretim programı, bu konu alanlarını temel alarak hazırlanmasına karşın bilimsel süreç becerileri, yaşam becerileri, duyuş ve FTTÇ öğrenme alanları ile ilişkilendirilmiştir. Kazanımlar, bilimsel bilginin;beceri, duyuş ve günlük yaşamla olan ilişkisi dikkate alınarak tasarlanmıştır. Sonuç olarak Fen Bilimleri konu alanları, sadece temel fen kavram ve ilkelerini değil, aynı zamanda bu ders kapsamında öğrencilere kazandırıması gereken beceri, duyuş ve FTTÇ ilişkilerini de içermektedir." (MEB, 2013, s. 5).

Programlar, ara disiplinler ve Atatürkçülük kazanımları kapsamında incelendiğinde Fen ve Teknoloji Dersi Öğretim programında ara disiplinlere(MEB, 2005, s.383-389) ve Atatürkçülü'ğe(MEB, 2005, s. 380-382) ilişkin kazanımların listelendiğive bu konuların kazanımları ile eşleştirme yapıldığı (MEB, 2005, s. 12, s. 81) ve Fen ve Teknoloji ders kitaplarında Atatürkçülü'ğe ilişkin etkinliklerin yer aldığıbelirlenmiştir (Fen ve Teknoloji 4. Sınıf Ders Kitabı, 2012, s. 61, 77, 207; Fen ve Teknoloji 5. Sınıf Ders Kitabı, s. 83, 110-111, 191-192; Fen ve Teknoloji 6. Sınıf Ders Kitabı, 2012, s. 22, 164; Fen ve Teknoloji 7. Sınıf Ders Kitabı, 2012, s. 57, 89, 245; Fen ve Teknoloji 8. Sınıf Ders Kitabı, 2012, s. 176). Yeni programlarda ise ara disiplin kazanımları ayrıca listelenmemiş, ancak bilgi öğrenme alanları başlığı altındaki kazanım ifadelerinin içinde yer almıştır. Ayrıca fen bilimleri programında Atatürkçülüğe ilişskin kazanımlara yer verilmemiş ve bu konuya ilişkin herhangi bir açıklamaya rastlanmamıştır.

Özetle; tablo 1, tablo 2 ve tablo 3 incelendiğinde dikkati çeken birinci husus, kazanım ifadelerinin Fen bilimleri programlarında daha genel ve kapsayıcı olmasıdır. Görüldüğü üzere 2005 programı kazanımları daha ayrıntılı olarak ifade edilmesidir. 2013 fen bilimleri programındaki birçok kazanım ise fen ve teknoloji programında yer alan 2 ve ya daha fazla kazanımı içinde barındıracak şekilde daha genel olarak ifade edilmiştir. Ancak bu durum kapsamın sınırlılığı konusunu belirsiz kılmaktadır. Dikkati çeken ikinci husus 2013 programlarında BSB, Tutum ve Değerler ve FTTÇAra disiplinler ve Atatürkçülük alanlarına ilişkin olarak ayrı kazanım listelerineyer verilmemesidir. EBA'da yer alan program tanıtımında bu hususla ilgili olarakbu kazanımların programın bilgi kazanımlarına "yedirildiği" ifadesi' nin kullanıldığı belirtilmişti. Ancak bunun her kazanım için yapılmadığı söylenebilir.

\subsubsection{5 ve 2013 Programlarının Kazanım Sayıları ve Dağılımı}

Bu soruya cevap verebilmek amacıyla örneklem olarak Madde ve Değişim öğrenme alanı incelemeye alınmış ve bu öğrenme alanına ilişkin tüm kazanımlar bütün sınıf düzeylerinde incelenmiş ve inceleme sonuçları tablolar halinde verilmiştir.

Tüm sınıf düzeylerinde madde ve değişim öğrenme alanı kazanım sayılarında ne tür değişikliklere gidildiğine ilişkin analiz verileri aşağıdaki tablolarda verilmiştir. İki sütunlu olan tabloların ilk sütununda 2005 programlarında yer alan ancak hem program hem de ders kitabı incelemesi sonucunda 2013 programlarında yer almadığı anlaşılan kazanımlara yer verilmiştir. Diğer taraftan tablonun ikinci sütununda ise 2013 programına eklenen ancak daha önce 2005 programında olmayan kazanımlara yer verilmiştir.

Tablo 4

2005 Fen ve Teknoloji Programından Çıkarılan ve 2013 Fen Bilimleri Programına Eklenen Kazanımlar Listesi (4. Sinıf) 


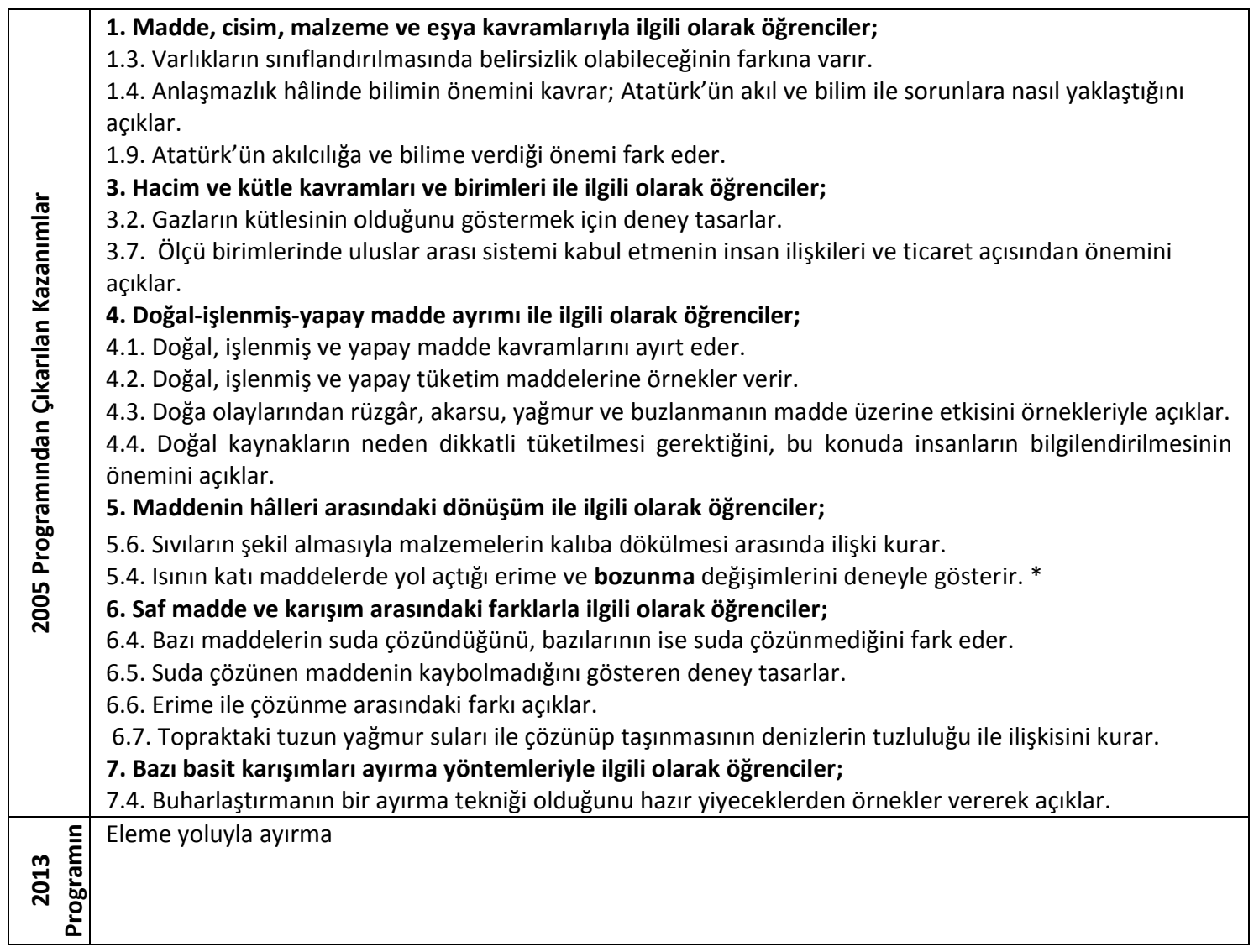

*(Yalnızca bozunma kavramı çıkarılmıştır)

Tablo 4 incelendiğinde 4. Sınıf düzeyinde 2005 programlarında yer alan 46 kazanımdan 14'ünün 2013 programında yer almadığı görülmektedir. 1 kazanımın (Kazanım 5.4) ise bir kısmının yer almadığı görülmektedir. Bununla birlikte 2013 programında maddenin halleri konusuna ilişkin olarak "aynı maddenin farklı halleri" konusuna ayrıca vurgu yapılmıștır. Karışımları ayırmaya ilişkin olarak ise 2005 programında yer alan buharlaştırma tekniğine karşın 2013 programında eleme yoluyla ayırma tekniğine yer verilmiştir. 2005 programında yer alan "Doğal-işlenmiş-yapay madde ayırımı" konusu ise 2013 fen programında hiç yer almamaktadır. Özet olarak, 4. Sınıfa ilişkin olarak kazanımlarda yaklaşık 1/3 oranında bir kısıtlamaya gidildiği görülmektedir.

Tablo 5

2005 Fen ve Teknoloji Programından Çıkarılan ve 2013 Fen Bilimleri Programına Eklenen Kazanımlar Listesi (5. Sinıf)

\section{KAZANIMLAR}




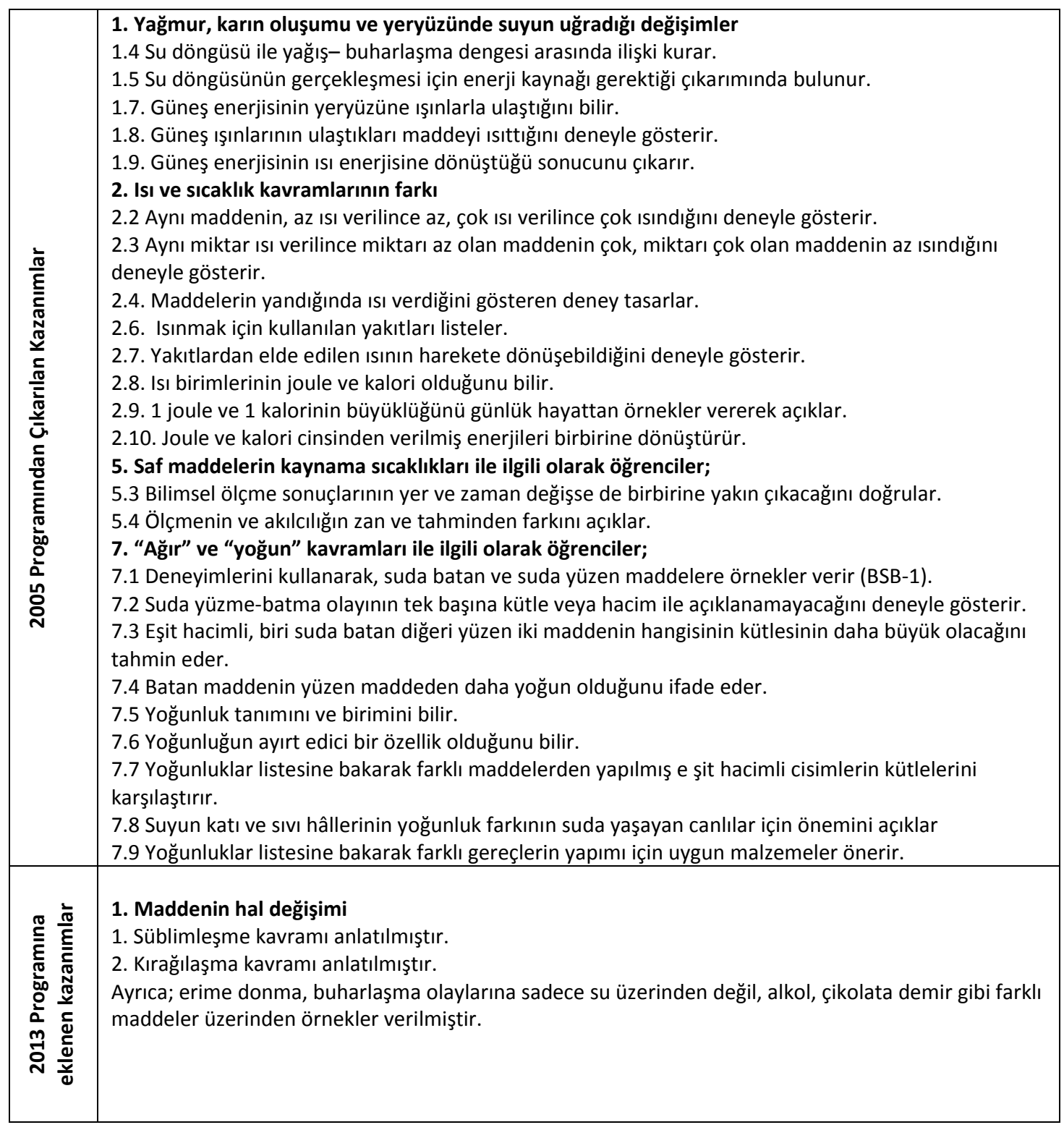

5. sınıfta fen ve teknoloji dersi programı ve ders kitabında "yağmur, kar oluşumu ve yeryüzünde suyun uğradığı değişimler" konusu kapsamında maddenin halleri konusunun suyun hallerine ilişkin olarak anlatıldığı ve örneklendirildiği görülmektedir. Ancak fen bilimleri dersi programı ve ders kitabında 2005 programından farklı olarak maddenin hal değişimi başlığı altında erime donma, buharlaşma olaylarına sadece su üzerinden değil, alkol, çikolata demir gibi farklı maddeler üzerinden de örnekler verildiği belirlenmiştir. Bunun yanında bu konu kapsamında fen ve teknoloji programında yer alan su döngüsü ve güneş enerjisi konuları 2013 programında yer almamaktadır. Ayrıca ISı ve sıcaklık kavramlarının farkına ilişkin olarak 5. Sınıfta neredeyse hiç kazanım yoktur. Fen ve teknoloji programında yer alan ağır ve yoğun kavramaları ile ilgili konunun fen bilimleri 5. Sınıf programlarında hiç yer almadığı ancak bu konunun 6. Sınıf programında 5. Sınıfta işlenen konu kazanımlarını kapsayacak şekilde işlendiği görülmektedir. Bu nedenle 5. Sınıfta bu konu işlenmemiş olarak değerlendirilmeyecektir. Buna göre 5. Sınıf programlarında fen ve teknoloji dersinde yer alan 46 kazanımdan 15 inin yeni programlarda yer almadığı görülmektedir. Bunun yanında fen bilimleri programında maddenin hal değişimi konusu kapsamında Fen ve teknoloji programından farklı olarak süblimleşme ve kırağılaşma kavramına yer verildiği görülmektedir. 
2005 Fen ve Teknoloji Programından Çıkarılan ve 2013 Fen Bilimleri Programına Eklenen Kazanımlar Listesi (6. Sinıf)

\begin{tabular}{|c|c|}
\hline & KAZANIMLAR \\
\hline 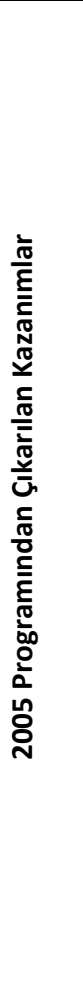 & $\begin{array}{l}\text { 1.6. Maddenin, küreye benzer yapı taşlarını atom şeklinde adlandııır. } \\
\text { 1.7. Atom kavramı ile ilgili düşüncelerin zaman içinde değiştiğini fark eder. } \\
\text { 1.8. Atomların daha da küçük parçacıklardan oluştuğunu ifade eder. } \\
\text { 2. Maddelerin özellikleriyle tanecikli yapısı arasında ilişki kurmak bakımından öğrenciler; } \\
\text { 2.1. Maddelerin farklı olmasından yola çıkarak atomların da farklı olabileceği sonucuna ulaşır. } \\
\text { 2.2. Aynı cins atomlardan oluşmuş maddeleri "element" şeklinde adlandııır. } \\
\text { 2.3. Bileşik modelleri üzerinde farklı element atomlarını ayırt eder. } \\
\text { 2.4. Farklı atomlar içeren saf maddeleri "bileşik" olarak adlandırır. } \\
\text { 2.5. Basit model veya resimler üzerinde molekülleri gösterir. } \\
\text { 2.6. Basit molekül modelleri yapar. } \\
\text { 2.7. Her molekülde belirli sayıda atom bulunduğu çıkarımını yapar. } \\
\text { 2.8. Model üzerinde molekül içeren ve içermeyen maddeleri birbirinden ayırt eder. } \\
\text { 3. Fiziksel ve kimyasal değişimlerin atom-molekül düzeyinde açıklaması ile ilgili olarak öğrenciler; } \\
\text { 3.5. Atom-molekül modelleri ile temsil edilmiş değişimlerde fiziksel ve kimyasal olayları ayırt eder. } \\
\text { 3.6. Çok sayıda atom ve molekül içeren maddelere bakarak, " saf madde" ve } \\
\text { atom ve molekül düzeyinde fark eder. } \\
\text { 2. Ünite. Madde ve Isı } \\
\text { 2. Isının yayılma yollarını ile ilgili olarak öğrenciler; } \\
\text { 2.4. Gündelik gözlem ve deneyimlerinden, doğrudan temas olmadan ısı aktarımı olabileceği çıkarımını } \\
\text { yapar. } \\
\text { 2.5. Isının ışıma yoluyla yayılabileceğini belirtir. } \\
\text { 2.6. Geceleri yeryüzünün neden soğuduğunu sorgulayıp açıklar. } \\
\text { 2.7. Yüzeyi koyu renkli cisimlerin, açık renklilerden daha hızlı ısınmasının sebebini açıklar. } \\
\text { 2.8. Isı yalıtım kaplarının yüzeylerinin neden parlak kaplandığını izah eder. } \\
\text { 2.9. Sıvılarda konveksiyon ile ısı yayılmasını deneyle gösterir. } \\
\text { 210. Isınıniletim konveksivon ve ısıma volu ile vavıldı̆ı̆ durumları avırt eder }\end{array}$ \\
\hline 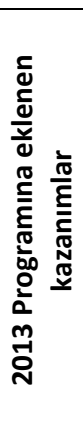 & $\begin{array}{l}\text { 1. Yoğunluğu tanımlar ve birimini belirtir. a. Yoğunluğun madde için ayırt edici bir özellik olduğu } \\
\text { vurgulanır. b. Yoğunluğun birimi olarak g/cm3 kullanılır. } \\
\text { 2. Tasarladığı deneyler sonucunda çeşitli maddelerin yoğunluklarını hesaplar. } \\
\text { 3. Birbiri içinde çözünmeyen sıvıların yoğunluklarını deney yaparak karşılaştırır. } \\
\text { 4. Suyun katı ve sıvı hâllerine ait yoğunlukları karşılaştırarak bu durumun canlılar için önemini sorgular } \\
\text { 2. Ünite. Madde ve Isı } \\
\text { Yakıtlar } \\
\text { 1. Yakıtları, katı, sıvı ve gaz yakıtlar olarak sınıflandırarak yaygın olarak kullanılan yakıtlara örnekler } \\
\text { verir. } \\
\text { 2. Farklı türdeki yakıtların ısı amaçlı kullanımının, insan ve çevre üzerine etkilerini araştırır ve sunar. } \\
\text { 3. Soba ve doğal gaz zehirlenmeleri ile ilgili alınması gereken tedbirleri araştırır ve rapor eder. }\end{array}$ \\
\hline
\end{tabular}

6. sınıfta dikkati çeken hususlardan biri Fen ve Teknoloji programında maddenin tanecikli yapısının anlatııışı sırasında "atom" konusuna giriş yapılmasıdır. 2013 fen bilimleri programında da maddenin tanecikli yapısı anlatılmış ancak atom kavramı tanımlanmamıştır. 2005 programında yer alan maddenin özellikleri ve tanecikli yapısı arasında ilişki kurmak konusu 2013 fen bilimleri programında hiç yer almamıştır. Ayrıca atom kavramında bahsedilmediğinden "Atom-molekül modelleri ile temsil edilmiş değişimlerde fiziksel ve kimyasal olayları ayırt eder" kazanımı ve "çok sayıda atom ve molekül içeren maddelere bakarak, " saf madde" ve " karışım" kavramlarını atom ve molekül düzeyinde fark eder" kazanımı 2013 programında temsil edilmemiştir. Bununla birlikte Fen bilimleri programında 5. Sınıfta işlenmeyen yoğunluk konusu 5. Sınıf fen ve teknoloji dersi programı kazanımları kapsamında işlenmiştir. Ayrıca 6. Sınıf Fen bilimlerinde yer alan "Yakıtlar" konusu Fen ve Teknoloji dersi 6 . Sınıf programında ve diğer sınıf düzeylerinin programında yer almamıştır. Fen ve teknoloji programında yer alan ısınsın yayılma yollarına ilişkin birçok kazanım ise Fen bilimleri programında yer almamıştır. Özetle; 2005 Fen ve Teknoloji Dersi programında yer alan 44 kazanımdan 19 tanesinin 2013 programında yer almadığı görülmektedir. Bunun yanında 
2005 Fen ve Teknoloji ve 2013 Fen Bilimleri Öğretim Programı Madde ve Değişim Öğrenme Alanı Kazanımlarının Karşılaştırmalı Analizi

2013 fen bilimleri programı kapsamında yer alan yakıtlar konusuna ilişkin 3 kazanımın Fen ve teknoloji programında yer almadığı görülmektedir.

Tablo 7

2005 Fen ve Teknoloji Programından Çıkarılan ve 2013 Fen Bilimleri Programına Eklenen Kazanımlar Listesi (7. Sinıf)

\begin{tabular}{|c|c|}
\hline & KAZANIMLAR \\
\hline 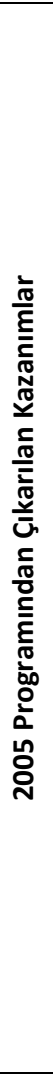 & 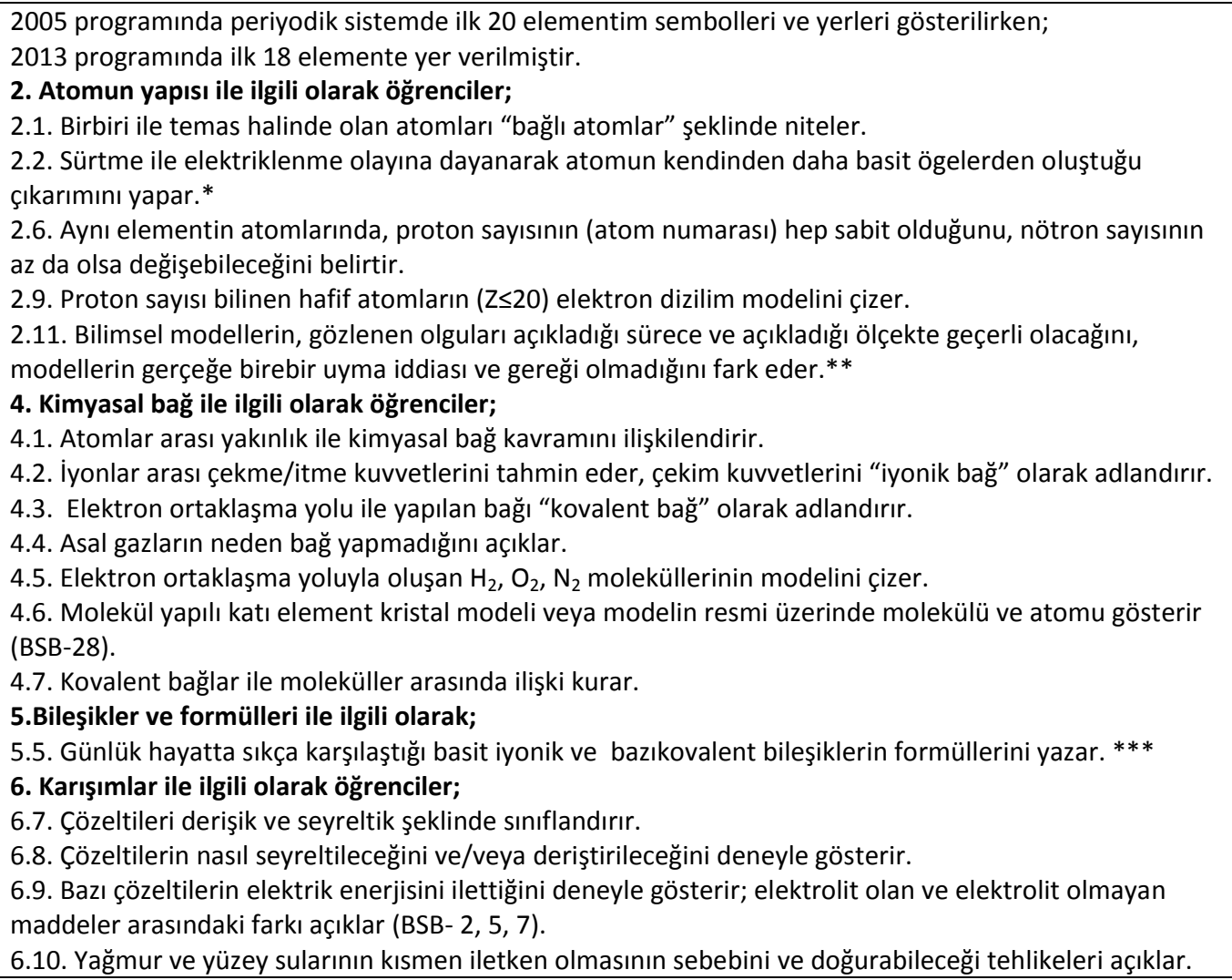 \\
\hline 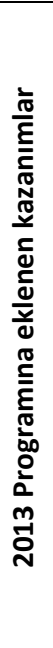 & $\begin{array}{l}\text { Karışımların Ayrıştırılması } \\
\text { 1. Karışımların ayrıştırılmasında kullanılabilecek bazı yöntemleri tahmin eder ve tahminlerini test eder. } \\
\text { Karışımların ayrıştırılmasında kullanılabilecek yöntemlerden buharlaştırma, yoğunluk farkı ve damıtma } \\
\text { üzerinde durulur. } \\
\text { Evsel Atıklar ve Geri Dönüşüm } \\
\text { 1. Evsel atıklarda geri dönüştürülebilen ve dönüştürülemeyen maddeleri ayırt eder. } \\
\text { 2. Evsel katı ve sıvı atıkların geri dönüşümüne ilişkin proje tasarlar. } \\
\text { 3. Geri dönüşümü, kaynakların etkili kullanımı açısından sorgular. } \\
\text { 4. Yakın çevresinde atık kontrolü sorumluluğunu geliştirir. } \\
\text { 5. Atık suların arıtımına yönelik model oluşturur ve sunar. } \\
\text { 6. Geri dönüşüm tesislerinin ekonomiye katkısını tartışır. } \\
\text { 7. Yeniden kullanılabilecek eşyalarını, ihtiyacı olanlara iletmeye yönelik proje geliştirir. } \\
\text { Kimya Endüstrisi } \\
\text { 1. Yakın çevresindeki kimya endüstrisi alanındaki işletmelerin, toplum ve ülke ekonomisine katkılarını fark } \\
\text { eder. } \\
\text { 2. Ülkemizdeki kimya endüstrisinin gelişimine katkı sağlayan resmi/özel kurum ve sivil toplum } \\
\text { kuruluşlarının yaptığı çalışmaları araştırır ve sunar. }\end{array}$ \\
\hline
\end{tabular}

*Atomun kendisinden daha küçük parçalara sahip olduğu model üzerinde gösterilmektedir. Ancak sürtme ile elektriklenmeden yola çıkarak çıkarım yapmalarına olanak verecek türde bir içeriğe fen bilgisi ders kitabında rastlanmamıştır.

**Bu kazanımda bir belirsizlik söz konusudur. Atom modellerinin verilmesinden sonra; geçmişten günümüze fikirlerin değiştiğini gören çocuklar bu modelin de yeni bilimsel gelişmeler ışığında değişip değişmeyeceğini kendi kendilerine de sorgulayabilirler. Ya da öğretmen bu konuda onların 


\begin{abstract}
düşünmesini sağlayabilir. Ancak ders kitapları incelendiğinde fen ve teknoloji ders kitabında konu bitiminde "Atom modellerinin tarihteki gelişimini ve günümüzdeki atom modelini de öğrendik. Buna göre "hacimli atom" gerçeğine en uygun model sizce hangisidir? Acaba atom hakkında bilinenler bu kadar mıdır ve zaman içerisinde bu fi kirler ne yönde değişecektir?" sorusunun sorulduğu, fen bilimleri ders kitabında ise böyle ve ya benzer bir sorunun yer almadığı sadece modern atom teorisinin açıklanıp bitirildiği görülmektedir.

***(fen ve teknoloji ders kitabında (s:177) iyonik ve kovalent bileşiklere örnekler verilirken fen bilgisi kitabında (s: 109) iyonik kovalent bileşik tanımlaması yapılmaksızın yaygın bileşik isimlerine ve formüllerine örnekler verildiği görülmektedir.

**** Çözünme hızına etki eden faktörler konusunda Fen bilgisi ders kitaplarında "sıcaklık ve temas yüzeyinin etkisi" yanında fen ve teknoloji ders kitaplarından farklı olarak "karıştırmanın çözünme hızına etkisi" de incelenmiştir (FB DK. 117).
\end{abstract}

7. sınıfta yer alan Fen ve Teknoloji programında yer alan ilk konuda ilk 201 elementin periyodik sistemdeki yeri ve sembolleri konusu işlenmiştir. 2013 fen programlarında da bu konuda kayda değer farklılık görünmemektedir. Fen ve Teknoloji Programında Periyodik tabloda ilk 20 element ele alınmışken, 2013 Fen bilimleri programında 18 element ele alınmıştır. Atomun yapısı konusu 7. Sınıf Fen bilimleri programında ilk defa işlenmiştir. Fen ve Teknoloji programında ise daha önce atom konusuna değinilmişti ve 7. Sınıf düzeyinde biraz daha üst düzeyde kazanımlara yer verildiği görülmüştür. Dikkati çeken kazanımlardan birisi Fen ve Teknoloji programında "atomun yapısı" konusuna ilişkin 2. Kazanımdır. Bu kazanım kapsamında yer alan atomun kendinden küçük parçacıklara sahip oluşu olgusu her iki programda da yer almaktadır. Ancak fen ve teknoloji dersi programında sürtme ile elektriklenme olayına dayanarak bu konuda çocukların çıkarım yapmaları hedeflenmiştir. Bu hedef BSB. 8 kazanımını (Olmuş olayların sebepleri hakkında gözlemlere dayanarak açıklamalar yapar) temsil etmektedir. 2013 fen bilimleri programında ise atomun kendisinden daha küçük parçalara sahip olduğu model üzerinde gösterilmektedir. Atom numarası kavramı ve kimyasal bağlar konusunun tamamı 7. Sınıf fen ve teknoloji dersi programında yer alırken fen bilimleri programında bu konulara 8. Sınıf dahil olmak üzere yer verilmemiştir. Fen bilimleri programında kimyasal bağlar konusuna değinilmediğinden bileşiklerin tanımlamasında iyonik ve kovalent bileşik kavramlarına değinilmediği görülmektedir. Karışımlar konusu kapsamında iyonik ve derişik çözeltiler, elektrolit ve elektrolit olmayan çözeltileri konuları Fen ve Teknoloji programında yer alırken Fen bilimleri programında yer almamıştır. Bunun yanında fen bilimleri programında fen ve teknoloji 7. Sınıf programından farklı olarak karışımların ayrıştırılması, evsel atıklar ve geri dönüşüm, kimya endüstrisi konularına yer verildiği görülmektedir. Özetle Fen ve Teknoloji programında yer alan 46 kazanımın yaklaşık 17 tanesine yeni programda yer verilmediği, buna karşılık yeni programda fen ve teknoloji programındaki kazanımlardan farklı olan 11 kazanıma yer verildiği görülmektedir. Bu durum, 7. Sınıf fen bilimleri programının kazanımlarında kayda değer bir kısıtlamaya gidilmediği yönünde yorumlanabilir.

Tablo 8

2005 Fen ve Teknoloji Programından Çıkarılan ve 2013 Fen Bilimleri Programına Eklenen Kazanımlar Listesi (8. Sinıf) 


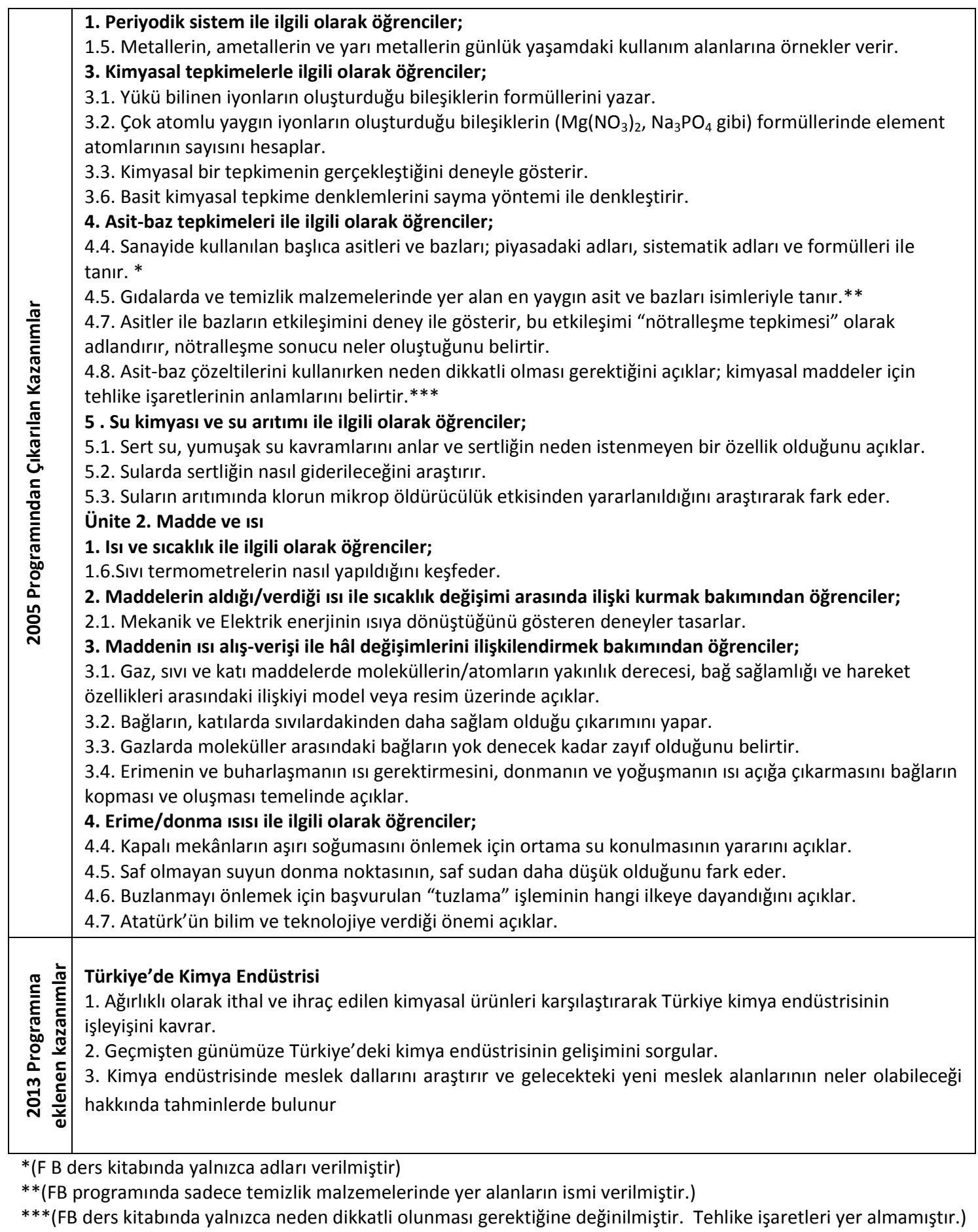

Fen ve teknoloji programı kapsamında yer alan metal, ametal ve yarı metallerin günlük yaşamdaki kullanımı, kimyasal tepkimelerde atom sayısını hesaplama, denkleştirmeye ilişkin kazanımlar 8. Sınıf fen bilimleri programında yer almamıştır. Ayrıca asit ve baz tepkimeleri ile ilgili bazı ayrıntıların fen bilimleri programlarına dahil edilmediği de görülmektedir. Bunun yanında suların arıtımına ilişkin fen ve teknoloji programında var olan konu fen bilimleri programına dâhil edilmemiştir. Madde ve ISI ünitesine ilişkin olarak sIVı termometreler konusuna yenilenen fen bilimleri programında yer verilmediği görülmektedir. Ayrıca atomlar arası bağlarla ilişki olan hal değişim konularına da değinilmemiştir. Erime ve donma ISISI konularının bazı ayrıntıları da 2013 programında görülmemektedir. Atatürkçülük ile ilgili 
kazanımlara programda yer verilmediğinden "Atatürk'ün bilim ve teknolojiye verdiği değerin önemini açıklama"ya ilişkin kazanımın da Fen Bilimleri programlarında olmadığı görülmektedir. Benzer bir kısıtlamanın diğer öğrenme alanlarında da mevcut olduğu görülmektedir. Bununla birlikte 2013 Fen bilimleri programında fen ve teknoloji programından farklı olarak Kimya Endüstrisi konularına değinildiği görülmektedir. Benzer bir durum 7. Sınıflarda da betimlenmişti. Her iki sınıf düzeyinde fen bilimleri programında Türkiye'de kimya endüstrisinin gelişimi konusuna değinilmiş, bunun yanında 8 . Sınıfta bu alandaki meslek alanlarının fark edilmesine dönük bir kazanıma yer verilmiştir. Özetle 8. Sınıf fen ve teknoloji programında yer alan 58 kazanımdan yaklaşık 22 tanesine fen bilimleri programında yer verilmemiştir. Buna karşılık fen ve teknoloji programında yer almayan ancak fen bilimleri programında yer alan 3 kazanım vardır.

\section{SONUÇ VE TARTIŞMA}

Bu araştırmada 2013 yılında uygulamaya konulan Fen bilimleri dersi ve 2005 yılında uygulamaya konulan Fen ve Teknoloji dersi öğretim programının kazanımlarıkarşılaştırımış ve her iki programın kazanımları karşılıklı olarak programların ve ders kitaplarının birlikte incelenmesiyle analiz edilmiştir.

2005 ve 2013 programları kazanımlarının yapısı karşılaştırmalı olarak incelendiğinde 2005 fen ve teknoloji programının kazanımlarının daha ayrıntı veren ifadelerden oluştuğu, 2013 fen bilimleri programı kazanımlarının ise daha genel ifadelerden oluştuğu belirlenmiştir. Fen bilimleri programının kazanımlarının fen ve teknoloji programında yer alan 2-3 kazanımı içerecek şekilde ifade edildiği belirlenmiştir. Bu durumda kazanımların hangi sınılılıkta kazandırılacağına ilişkin olarak bir belirsizlik hissedilmektedir. Benzer şekilde Çıray, Küçükyılmaz ve Güven (2015) yaptıkları çalışmada öğretmenlerin kazanım ifadelerinin belirsiz olduğu, net olmadığı konusunda görüş bildirdiklerini belirtmiş̧lerdir.Bunun yanında Fen Bilimleri programında BSB, FTTÇ ve duyuş alanına ilişkin olarak kazanımların listelenmediği görülmektedir veprogramda ne şekilde temsil edileceğine dair yeterli açıklamalar yer almamaktadır.MEB program tanıtımlarında bu alanlara ilişkin kazanımların bilgi temelli öğrenme alanı kazanımlarına yedirildiği belirtilmiştir. Bu durumda FTTÇ, Duyuş ve Bilimsel süreç becerileri ve ara disiplin kazanımlarının ilişkilendirmesinin yeni programlarda daha çok öğretmenin sorumluluğuna bırakıldığı söylenebilir. Ayrıca Atatürkçülüğe ilişkin herhangi bir kazanıma rastlanmamıştır ve dolayısıyla fen bilimleri ders kitaplarındaAtatürkçülüğe ilişkin konulara yer verilmemiştir. Program hazırlayıcıların verdiği bilgilere göre FTTÇ, Duyuş ve Bilimsel süreç becerileri ve ara disiplin kazanımları, bilgi kazanımlarına yedirilmiştir (Fen Bilimleri Dersi (3-8. Sınıflar) Öğretim Programı Tanıtımı, 2013). Ancak bu konuda da belirsizlik söz konusudur. Eskicumalı ve ark. (2014) kazanımların ifade edilmeyişinin programın uygulamasında ve kazanımların edinilmesinde öğretmenlere zorluklar doğurabileceğini belirtmişlerdir. Bulgular göz önünde bulundurularak programların uygulanmasında kapsamın sınırlıı̆ını ve beceri alanlarında yapılabilecek olan uygulamaları belirleyebilmek adına ders kitabına eskiye oranla daha fazla ihtiyaç duyulacağı düşünülmektedir.

Dördüncü sınıf düzeyinden sekizinci sınıf düzeyine kadar 2005 ve 2013 programlarının kazanımlarının ne düzeyde sınırlandırıldığını ve değiştiğini belirlemek adına madde ve değişim öğrenme alanının kazanımları karşılaştırmalı olarak analiz edilmiştir. Analiz sonucunda görülmüştür ki 7. Sınıf hariç, neredeyse tüm sınıf düzeylerinde madde ve değişim ünitesine ait olan kazanımlarda yaklaşık $1 / 3$ oranında azaltmaya gidilmiştir. Benzer bir araştırmanın sonucuna göre kazanımlarda \%65 dolaylarında bir kısıtlamaya gidildiğini belirlenmiştir (Karatay, Timur ve Timur, 2013). Bu kısıtlamanın öğretmenler tarafından olumlu olarak algılandığını belirten araştırmalar mevcuttur (Çıray, Küçükyılmaz ve Güven, 2014; Elmas, Aydoğdu ve Saban, 2014; Özcan ve Küçükoğlu, 2014). Benzer şekilde Toraman ve Alcı (2013) tarafından yapılan 
araştırmada konuların içeriğinin azaltılmasının ve hedeflerde gerçekleştirilen değişikliklerin öğretmenlerin büyük çoğunluğu tarafından olumlu karşılandığı belirlenmiştir. Ancak yine de öğretmenlerden bazıları kazanımların azaltılmasını bir "silme işlemi" olarak algılamışlar ve bu işlemin öğrencilerin konuları ilişkilendirmesinde soruna yol açacağını düşündüklerini belirtmişlerdir (Toraman ve Alcı, 2013, s. 20). Benzer şekilde kazanımların azaltılmasının olumsuz sonuçları olabileceğine ilişkin araştırmalara rastlamak mümkündür. Uygur ve Uygur (2014) tarafından yapılan araştırmada cinsel eğitimin çoğunlukla fen dersleri bünyesinde verilebildiği, 2004 yılında geliştirilen fen programlarına kıyasla 2013 programlarında cinsel eğitime ilişkin kazanımların azaltıldığı belirtilmiş ve bu durum olumsuz bir düzenleme olarak değerlendirilmiştir. Daha önce de belirtildiği gibi MEB program tanıtımında (Fen Bilimleri Dersi (3-8. Sınıflar) Öğretim Programı Tanıtımı, 2013) programın gerekçesi olarak daha sade ve anlaşılır bir program ihtiyacından dolayı programların yenilendiği belirtilmişti. Bu nedenle bir programda sadeleştirme nasıl olmalıdır ve neden yapılmalıdır soruları tartışılmaya değer sorulardır.

\section{4.ÖNERILER}

Bu araştırma fen programlarının özellikle kazanım öğesindeki değişikliklerin analizini ortaya koymaktadır. Bilindiği üzere ülkemizde programlar belirli aralıklarla değişmektedir. Değişen programların ne yönde, nasıl değiştiğini analiz etmek eleştirilere uygun bir bilgi temeli sağlayacaktır. Bu nedenle programlardaki değişikliklerin doküman incelemesi ve öğretmen görüşleri yoluyla analiz edilmeye devam edilmesi gerekmektedir. Araştırmanın sonuçlarına göre programların kazanımlarının ifade edilişinde, kazanımların sayısında, ara disiplin ve Fen'e özgü beceri kazanımlarında önemli değişiklikler yapılmıştır. Bundan sonraki araştırmalarda bu değişikliklerin gerekliliği, önemi, işe yararlılığı öğretmen, öğrenci, veli, uzman görüşlerine başvurularak ortaya konabilir.

Bununla birlikte beceri temeli öğrenmelerin, FTTÇ ve duyuş öğrenme alanlarının kazanımlarının programlarda ayrıca listelenmediği ancak diğer kazanımların arasında temsil edildiğibelirlenmişti. Bu durumda bu öğrenme alanlarının programlarda ne düzeyde yer aldığının, öğretmenler tarafından anlaşılıp anlaşılmadığının ve uygulanabilir olup olmadığının ortaya çıkarılmasına yönelik araştırmalara ihtiyaç vardır.

\section{KAYNAKLAR}

Aydın, S.ve Çakıroğlu, J. (2010). İlköğretim Fen ve Teknoloji Dersi Öğretim Programına Illişkin Öğretmen görüşleri: Ankara Örneği, ilköğretim Online, 9 (1), 301-315.

Çepni, S. ve Çil, E. (2016). Fen Bilimleri Dersi Öğretim Programı-ilkokul ve Ortaokul Öğretmen El Kitabı, Ankara: Pegem A Yay.

Çıray, F.,Küçükyılmaz, E.A. ve Güven, M. (2015). Ortaokullar İçin Güncellenen Fen Bilimleri Dersi Öğretim Programına Yönelik Öğretmen Görüşleri, Dicle Üniversitesi Ziya Gökalp Eğitim Fakültesi Dergisi. 25(2015), 31-56

Elmas, R. Aydoğdu, B. ve Saban, Y. (2014). 2013 Fen Bilimleri Dersi Öğretim Programının Değerlendirilmesi,11. Ulusal Fen Bilimleri ve Matematik Eğitimi Kongresi Bildiri Özet Kitapçı̆̆ı, Adana.

Ertürk, S. (1972). Eğitimde Program Geliştirme, Ankara: Meteksan

Eskicumalı, A., Demirtaş, Z., Erdoğan, D. G. \& Arslan, S. (2014). The comparison of the science and technology curriculum and renewed science curriculum, International Journal of Human Sciences, 11(1),p. 1077-1094. 
Fen Bilimleri Dersi (3-8. Sınıflar) Öğretim Programı Tanıtımı (2013). http://www.eba.gov.tr/video/izle/866271d8e82c13aa94574b8bd34d31690325d81ed60 09. Yayım tarihi: 12.09 .2013$.

Görgen, i. (2012). Program Geliştirmede Temel Kavramlar, Hasan Şeker (Ed.) Eğitimde Program Geliştirme: Kavramlar-Yaklaşımlar içinde (s. 1-18),Ankara: Anı

Gündüz, G. (2016). Fen Bilimleri Dersi 7. Sınıf Kitabı. Ankara: Sonuç

Güneş, B. (Ed.) (2012). Fen ve Teknoloji Dersi 8. Sınıf Kitabı (5. Baskı). Ankara: MEB Devlet Kitapları

Leblebicioğlu, G. (Ed.) (2012). Fen ve Teknoloji Dersi 4. Sınıf Kitabı (3. Baskı) . Ankara: MEB Devlet Kitapları

Karaman, P. ve Karaman, A. (2016). Fen Bilimleri Öğretmenlerinin Yenilenen Fen Bilimleri Öğretim Programına Yönelik Görüşleri,Erzincan Üniversitesi Eğitim Fakültesi Dergisi, 18 (1).

Karatay, R., Timur, S. ve Timur, B. (2013). 2005 ve 2013 yılı Fen Dersi Öğretim Programlarının Karşılaştırılması,Adıyaman Üniversitesi Sosyal Bilimler Enstitüsü Dergisi, 6(15),

Kaya, O. N., Ünsal, Y., Balım, A. G., Erdoğan, M. Tüysüz, C. (Ed.) (2016). Fen Bilimleri Dersi 5. Sınıf Kitabı. Ankara: MEB Devlet Kitapları

Kıroğlu, K. (2006). Öğreten ve Öğrenenler için ek açıklamalarla Yeni ilköğretim programları, Ankara: Pegem-A .

Leblebicioğlu, G. (Ed.) (2012). Fen ve Teknoloji Dersi 5. Sınıf Kitabı(3. Baskı). Ankara: MEB Devlet Kitapları .

Leblebicioğlu, G. (Ed.) (2012). Fen ve Teknoloji Dersi 7. Sınıf Kitabı (1. Baskı).Ankara: MEB Devlet Kitapları:

MEB. (2005). Illköğretim Fen ve Teknoloji Dersi (4. ve 5. Sınıflar) Öğretim Programı (Erişim Tarihi: 25.04.2016).www.meb.gov.tr/TTKB.

MEB. (2012). 12 Yıllık Zorunlu Eğitim. Sorular-Cevaplar (Erişim Tarihi:03.10.2016). www.meb.gov.tr .

MEB. (2013). Illköğretim Kurumları( Illkokul ve Ortaokul) Fen bilimleri 3-4-5-6-7-8 Öğretim Programı.(Erişim Tarihi: 25.04.2016).www.meb.gov.tr/TTKB.

Özcan, H. ve Küçükoğlu, M. (2014). 2004 ve 2013 Fen Öğretim Programlarının Kazanımlar Açısından Karşılaştırılmasına Yönelik Öğretmen Görüşleri, 11. Ulusal Fen Bilimleri ve Matematik Eğitimi Kongresi Bildiri Özet Kitapçı̆̆ı, Adana.

Sönmez, V. (1993). Program Geliştirmede Öğretmen El Kitabı, Ankara: Adım Yayıncılık.

Taşar, M. F. (Ed.) (2012). Fen ve Teknoloji Dersi 6. Sınıf Kitabı (2. Baskı) . Ankara: MEB Devlet Kitapları

Toraman, S. ve Alcı, B. (2013). Fen ve Teknoloji Öğretmenlerinin Yenilenen Fen Bilimleri Dersi Öğretim Programına İlişkin Görüşleri, EKEV Akademi Dergisi, 56(56), 11-22.

Urhan, A. (2016). Fen Bilimleri Dersi 8. Sınıf Kitabı. Ankara: Tutku 
2005 Fen ve Teknoloji ve 2013 Fen Bilimleri Öğretim Programı Madde ve Değişim Öğrenme Alanı Kazanımlarının Karşılaştırmalı Analizi

Uygur, E. ve Uygur, M. (2014). 2004 ve 2013 Yılı Ortaokul Fen Bilimleri Dersi Öğretim Programlarının Cinsel Eğitim Yönünden Karşılaştırılması,Fen Bilimleri Öğretimi Dergisi,2(2), s. 95-109

Ünsal, Y. (Ed.) (2016). Fen Bilimleri Dersi 4. Sınıf Kitabı. Ankara: MEB Devlet Kitapları Ünsal, Y. (Ed.) (2016). Fen Bilimleri Dersi 6. Sınıf Kitabı. Ankara: MEB Devlet Kitapları Varış, F. (1997). Eğitimde Program Geliştirme, Ankara: Alkım Yay.

Yücel, E. Ö. ve Özkan, M. (2013). 2013 Fen Bilimleri Programının 2005 Fen ve Teknoloji Programıyla Çevre Konuları Açısından Karşılaştırılması.,Uludağ Üniversitesi Eğitim Fakültesi Dergisi,26(1), 237-265. 


\section{SUMMARY}

As is the case in many countries, Turkey as well has recently undergone remarkable restructuring in school curricula. In 2004, the Ministry of National Education and the Board of Education jointly revised curricula through a restructuring approach taking into account the insufficiency of curricula then existed, unsatisfactory performance in international student assessments, and the need to improve quality in education and ensure integrity in courses. Following a period of implementation of the new curricula there was transition to graded compulsory education of 12 years in the school year 2012-2013. In this new system, the first 4 years in education is defined as primary, the second 4 years as secondary, and the last 4 years as high school education. Immediately after this transition, the Minister of National Education at the time announced that curricula would be renewed accordingly, and following this renewal the new curricula took effect in 2013.

It is crucially important to analyse what comes in as new while launching this type of changes and arrangements in the system and curricula. It is well established that achievements guide other elements in the programme and they may thus be regarded as the most important element in any given programme. The mention of any change in achievements requires a detailed analysis of what kind of arrangements are made in curricula. However, studies presently existing in the body of relevant literature seem to be insufficient. Hence it is considered as necessary to analyse the dimension of achievement in comparison to the earlier curricula. Studies involving the analysis of changes and rearrangements in curricula may shed light on and guide future arrangements. The purpose of the present study is to analyse in comparative terms the achievements of the Sciences curriculum applied in 2013 and Sciences and Technology curriculum applied in 2013. It is expected that this analysis will demonstrate clearly and in detail the points that the 2013 curriculum differs from the one in 2005, and thus provide concrete and in-depth information to teachers, curriculum development experts and researchers regarding achievements in respective programmes. In this context the major questions posed are "What kind of structural differences are there between the achievements of the 2005 and 2013 curricula?" and "Do 2005 and 2013 curricula differ with respect to achievements in quantitative terms and their distribution by grades?"

The study is based on document analysis as a qualitative research method. Documents examined include the sciences curriculum first applied in 2013, sciences and technology curriculum applied in in 2005, and textbooks associated with these curricula as approved by the Ministry of National Education (MoNE). A specific field of learning (Matter and Change) was selected so as to cover all grades and related student achievements were examined. In order to identify changes, achievements in the field of learning, "Matter and Change" which existed in both curricula were compared with respect to all grades, and data obtained were analysed in content.

The study shows that achievements associated with the 2005 sciences and technology curriculum comprise statements that are more detailed in content while the other consists of more general statements. It is observed that there is no list of achievements related to scientific process skills (SPS), science, technology, society, environment (STSE), and affective domain in the sciences curriculum and no sufficient explanation as to how they should be represented in the curriculum. It is stated in the MoNE curricula introductions that achievements in these fields have been instilled in achievements associated with the field of knowledge based learning. The case being so, the association of achievements in STSE, affective domain, SPS, and intermediary discipline with knowledge achievements is left to the responsibility of the teacher in the new curricula. Further, since there is no mention of any achievement related to the ideas of Atatürk in the new curricula, textbooks in sciences contain no related unit.

The analysis conducted to identify to what extent achievements of the 2005 and 2013 programmes are limited and changed from grade 4 to grade 8 shows that in all grades with the exception of grade 7, there is about one-third reduction in achievements related to the unit "matter and change".

This study gives an analysis of changes in achievements related to sciences curricula. As well known, curricula change in specific intervals in Turkey. Analysing how these changes is made and in which direction will provide an information base for criticism. Hence there is need to keep analysing 
2005 Fen ve Teknoloji ve 2013 Fen Bilimleri Öğretim Programı Madde ve Değişim Öğrenme Alanı Kazanımlarının Karşılaştırmalı Analizi

Güngör KESKINKILIÇ YUMUŞAK

changes in curricula through document analysis and teachers' opinions. Upon the outcomes of relevant studies important changes have taken place in the formulation of achievements, number of achievements, and skill acquisition in intermediary discipline and sciences. In future studies, the need for, importance and benefits of these changes can be exposed by soliciting opinions of teachers, students, parents and experts. It must be noted that achievements in skills based learning, STSE, and affective domains are instilled in other achievements instead of being listed separately. Given this, there is need to investigate to what extent these fields of learning are included in programmes, whether teachers have grasped it and found as applicable. 